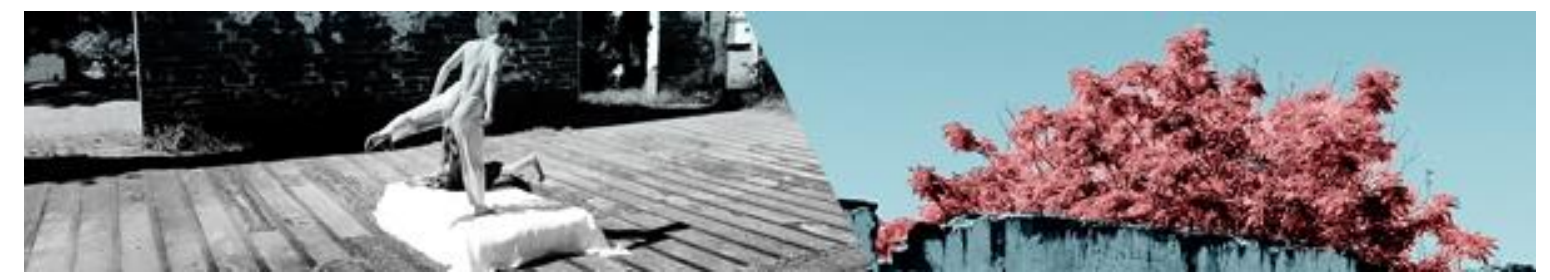

\title{
CONTRAPONTO EM REFLEXÃO SOBRE A PRÁTICA DO BALÉ: ESCAVANDO CAMADAS ÓSSEAS PARA A OBSERVAÇÃO DO MESTRE DE DANÇA ATRAVÉS DAS CARTAS DE JEAN-GEORGES NOVERRE
}

\author{
Robson Lourenço ${ }^{1}$ \\ Júlia Ziviani Vitiello²
}

\begin{abstract}
Resumo: Este artigo pondera sobre as reflexões desenvolvidas por Jean-Georges Noverre a partir do campo do conhecimento da anatomia. Apresenta e tece comentários sobre trechos da obra "Cartas sobre a Dança" (1998) e da edição de "Lettres sur les arts imitateurs en general et sur la danse en particulier" (1807). No texto aqui apresentado há um recorte a respeito dos conhecimentos anatômicos apresentados por Noverre e permite uma associação com o contexto da dança cênica vivenciado pelo artista. Além disso, elenca os autores estudados pelo artista para compor seus pensamentos, com o intuito de mostrar o entrelaçamento de sua experiência corporal em dança aos fundamentos da anatomia e à nascente ciência da mecânica de movimento.
\end{abstract}

Palavras-Chave: Dança; Balé; Anatomia; Dramaturgia; Corpo.

\begin{abstract}
${ }^{1}$ Robson Lourenco - Bacharel em Jornalismo pela Faculdade de Comunicação Cásper Líbero, é Mestre em Artes pela Universidade Estadual de Campinas e Doutor em Artes da Cena pela mesma instituição. É docente do Curso de Dança e Teatro da Universidade Anhembi-Morumbi, onde atua na área de ensino de dança, consciência corporal para bailarinos e atores e ao coordenar os Trabalhos de Conclusão de Curso de Dança e Movimento. No Curso de Licenciatura em Dança atua também como Supervisor de Estágios, orienta as monografias dos Trabalhos de Conclusão da Licenciatura e supervisiona o projeto de extensão "Todos na Dança Expandido". Integrou o elenco do Balé da Cidade de São Paulo de 1993 a 2008, quando atuou como solista nas principais produções da companhia no período. Desenvolve a integração entre procedimentos de percepção do esqueleto humano às técnicas de dança do balé e também desenvolve pesquisas dentro de fundamentos inspirados na dança moderna americana, principalmente aqueles ligados à atuação dos artistas Dóris Humphrey e José Limón. Atua desde 2006 na interação Arte \& Ciência e tem como foco de pesquisa Embriologia Humana e Anatomia Comparada, quando desenvolve ferramentas pedagógicas para o ensino destes conteúdos no âmbito acadêmico, artístico e social. Atuou como bailarino do Balé da Cidade de São Paulo de 1993 a 2008. É integrante do grupo de pesquisa Dançaberta da UNICAMP. Atua principalmente nos seguintes temas: Arte, Dança, Criação, Técnicas de Dança, Consciência Corporal, Arte-Educação e Arte \& Ciência.

2 Júlia Ziviani Vitiello - Possui graduação em Bachelor of Arts - New York University (1990), mestrado em Master Of The Fine Arts Dance - New York University (1991) e doutorado em Educação pela Universidade Estadual de Campinas (2004) e pós graduação na University of Colorado at Boulder.. Atualmente é professor pleno do Instituto de Artes - Unicamp, concepção e criação de figurinos e adereços da Universidade Estadual de Campinas, diretora artística da Universidade Estadual de Campinas, Dançaberta: pesquisa, criação e apresentação da Universidade Estadual de Campinas e produção geral da Universidade Estadual de Campinas. Tem experiência na área de Artes, com ênfase em Execução da Dança, atuando principalmente nos seguintes temas: dança, educação somática, arte, produção artística e dança contemporânea.
\end{abstract}

LOURENÇO, Robson; VITIELLO, Júlia Ziviani. Contraponto em reflexão sobre a prática do balé: escavando camadas ósseas para a observação do mestre de dança através das cartas de JeanGeorges Noverre. Revista da FUNDARTE, Montenegro, p.484-504, ano 19, ํㅜ 37, Janeiro/Março. Disponível em: http://.seer.fundarte.rs.gov.br/index.php/RevistadaFundarte/index $>30$ de março de 2019. 


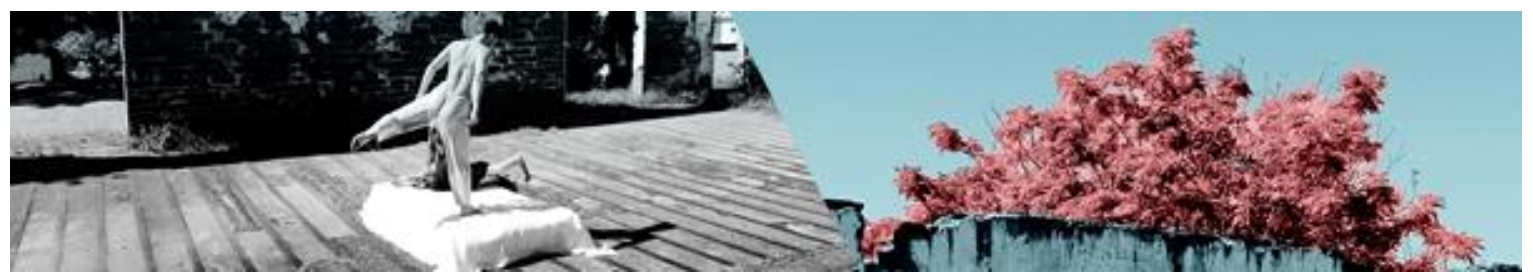

\title{
COUNTERPOINT IN REFLECTION ON THE PRACTICE OF BALLET: DIGGING BONY LAYERS FOR THE DANCE MASTER OBSERVATION THROUGH THE JEAN-GEORGES NOVERRE'S LETTERS
}

\begin{abstract}
This article ponders over the reflections Jean-Georges Noverre developed on the basis of anatomic knowledge. It presents and comments on excerpts from the book "Cartas sobre a Dança" (1998) and the edition of "Lettres sur les arts imitateurs en general et sur la danse en particulier (1807). There is a clipping in the text presented herein regarding the anatomical knowledge Noverre introduced that enables an association to the context of the scenic dance the artist experienced. It lists the authors Noverre studied in order for him to form his ideas, which purpose to show the interlacement of his bodily experience in dance to the fundamentals of anatomy and to the rising science of motion mechanics.
\end{abstract}

Keywords: Dance; Ballet; Anatomy; Dramaturgy; Body.

Este artigo reflete a partir da obra literária de Jean-Georges Noverre e desenvolve um recorte sobre como o artista francês ponderou sobre o campo de conhecimento da Anatomia. Serão abordados ao longo do texto as reflexões de Noverre sobre os membros inferiores e também as estruturas osteomusculares das regiões do rosto e do pescoço. Apresenta trechos e tece comentários sobre os pensamentos de Jean-Georges Noverre a partir da versão brasileira de Marianna Monteiro (1998) sobre "Lettres sur la danse". Esta reflexão também se debruça sobre o capítulo que o artista francês escreveu sobre os saberes anatômicos necessários ao mestre de dança, que estão contidos na edição de 1807, de sua obra "Lettres sur les arts imitateurs en general et sur la danse em particulier". Antes de apresentarmos os trechos das cartas sobre as reflexões anatômicas desenvolvidas por Noverre e escolhidas para serem abordadas neste artigo, apresentaremos um breve histórico do artista para, posteriormente, encaminhar a reflexão.

Segundo a pesquisadora brasileira Marianna Monteiro (1998), Noverre iniciou sua carreira em dança na adolescência, quando começou a estudar na Academia Real de Música e Dança, um centro criado pelo rei Luís XIV, em 1672, que antecederia a futura Ópera de Paris. Esse centro de estudos teria a função de sistematizar os caminhos para a dança cênica francesa daquele período.

Noverre foi discípulo de Louis Dupré3 na Academia Real francesa, e a

\footnotetext{
${ }^{3}$ Louis Dupré (1689-1774) - Bailarino e mestre de dança francês, especializado no estilo nobre de

LOURENÇO, Robson; VITIELLO, Júlia Ziviani. Contraponto em reflexão sobre a prática do balé: escavando camadas ósseas para a observação do mestre de dança através das cartas de JeanGeorges Noverre. Revista da FUNDARTE, Montenegro, p.484-504, ano 19, ํㅜ 37, Janeiro/Março. Disponível em: http://.seer.fundarte.rs.gov.br/index.php/RevistadaFundarte/index> 30 de março de 2019.
} 


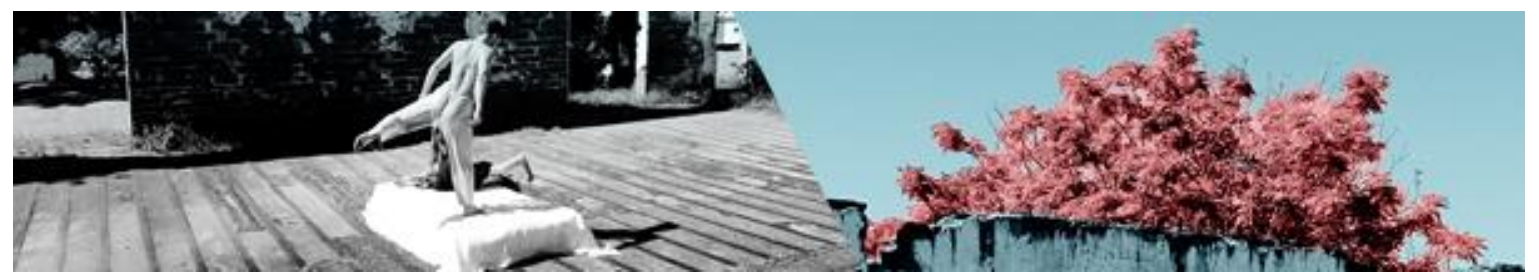

partir da formação recebida, poderia desenvolver um contraponto para frutificar o que seria a transmissão atualizada do conhecimento desenvolvido na Academia Real, ou apenas reproduzi-lo. Noverre optou pelo primeiro caminho, ao propor reflexões que atualizariam o conhecimento da dança realizada até aquele momento na França e integrar duas camadas de sua carreira: a elaboração de um número grande de produções coreográficas e a sua produção escrita.

Segundo a historiadora americana Jennifer Homans (2012), Noverre compôs em toda a sua carreira cerca de oitenta balés e vinte e quatro óperas-balés. Essa quantidade de obras foi produzida em inúmeras cidades, como Lyon, Stuttgart, Viena e Londres. Desse modo, a carreira de Noverre como artista foi sedimentada na madeira de diversos palcos europeus, quando teve a possibilidade de comparar e confrontar a cultura recebida em sua formação como artista, na França, com o saber desenvolvido nos teatros e em ambientes de dança daqueles diferentes países onde atuou.

A pesquisadora brasileira Marianna Monteiro (1998) afirma que a "reflexão de Noverre caracteriza-se por ver a dança, do ponto de vista do palco, como alguém que, ao longo da vida, foi atuante nesse mundo da dança, e não pôde impedir que essa experiência se refletisse em seus escritos teóricos" (MONTEIRO, 1998, p. 24).

Além do conhecimento desenvolvido nos palcos, Noverre também cunhou uma obra teórica, cuja reflexão foi feita sobre a prática observada e vivida como artista. Suas ideias sobre a dança cênica desenvolvida naquele momento foram escritas no formato "carta". Sobre esse fato, Marianna Monteiro (1998) declara que a escolha pelo formato "carta" traria um recurso que não seria arbitrário, pois:

serve para que suas ideias organizem-se em vários planos simultaneamente, definindo uma rede de temas e subtemas extremamente imbricados que tecem a obra, podendo, de alguma forma, ser assimilados à sinuosidade dos arabescos rococós. Incerto e ondulante, tal é o texto de Noverre. Os temas insinuam-se, apagam-se, dão lugar a outros temas; depois retornam e voltam a apagar-se, numa fluidez ígnea, caracterizando

dançar. Além de Noverre, teve como seu aluno Gaetan Vestris (FARO, 1989, p. 130-1)

LOURENÇO, Robson; VITIELLO, Júlia Ziviani. Contraponto em reflexão sobre a prática do balé: escavando camadas ósseas para a observação do mestre de dança através das cartas de JeanGeorges Noverre. Revista da FUNDARTE, Montenegro, p.484-504, ano 19, ํo 37, Janeiro/Março. Disponível em: http://seer.fundarte.rs.gov.br/index.php/RevistadaFundarte/index> 30 de março de 2019. 


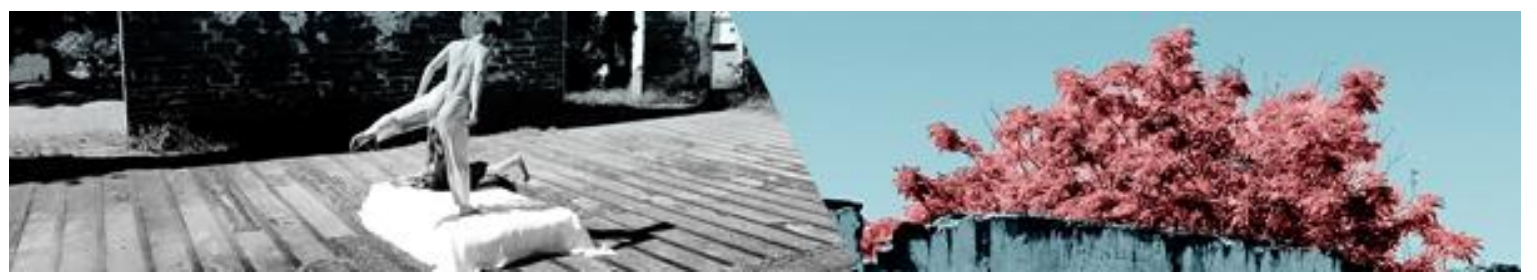

um discurso que jamais perde a agilidade, a leveza ou o tom mundano. (MONTEIRO, 1998, p. 28).

Seu primeiro conjunto de reflexões recebeu o título de "Lettres sur la danse" e começou a ser escrito em 1757, três anos antes de sua publicação em Stuttgart, em 1760, quando foi convidado pelo ator inglês David Garrick a passar um período de convalescença de uma doença em Londres.

Segundo Edward Nye (2012), aquele período de contato com Garrick propiciou a Noverre não só a oportunidade de escrever sua obra teórica, mas também alterou sua percepção sobre o corpo na cena ao ver o artista inglês em atuação. Tal contato com David Garrick levou Noverre a refletir sobre quais seriam as possibilidades do corpo na dança e como seria possível refletir sobre a preparação de artistas da dança para a cena.

\section{A anatomia como recurso para a observação do corpo}

A reflexão sobre a ação do corpo na dança seria um dos focos de Noverre em suas Cartas, e, sob esse prisma, seu olhar também se voltaria para algumas convenções desenvolvidas pelos mestres da Academia Real de Dança e Música Francesa. Entre as sistematizações criticadas por Noverre dentro de seu primeiro conjunto de cartas publicado em 1760, há ponderações críticas em relação às cinco posições de balé, que foram criadas por Pierre Beauchamps, um dos precursores da organização técnica da dança cênica desenvolvida naquele momento na França.

Para compreender a crítica desenvolvida por Noverre em suas cartas, apresentaremos um breve histórico sobre a gradual codificação das cinco posições na técnica do balé, para em seguida apresentar a crítica e a reflexão de Noverre sobre tais posições - incluindo seus estudos anatômicos sobre a relação entre pelve e pés.

A rotação externa dos membros inferiores era utilizada dentro das danças sociais da corte, e o responsável pela codificação das cinco posições do balé é 


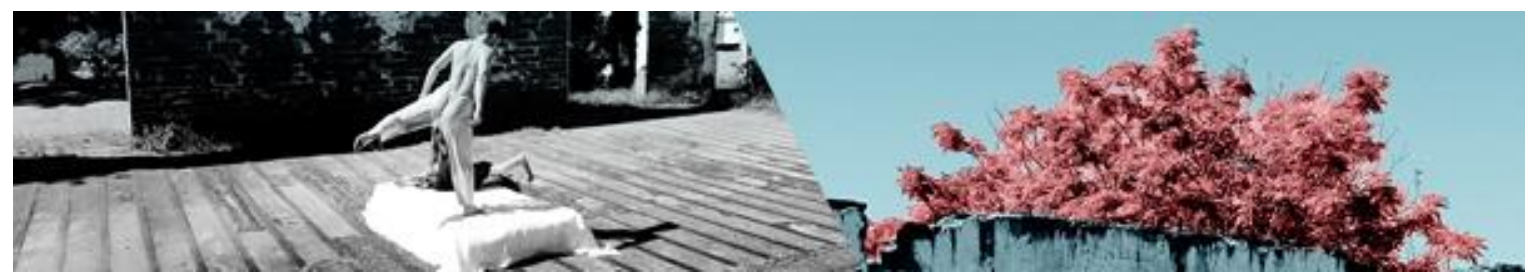

considerado Pierre Beauchamps. No entanto, Beauchamps não deixou, por escrito, nenhum tratado sobre sua sistematização, mas tais posições foram explicadas dentro das obras de Raoul Feuillet e de Pierre Rameau, publicados em 1700 e 1725, respectivamente. A seguir apresentamos as cinco posições de pés dentro do Tratado de Rameau (1725):

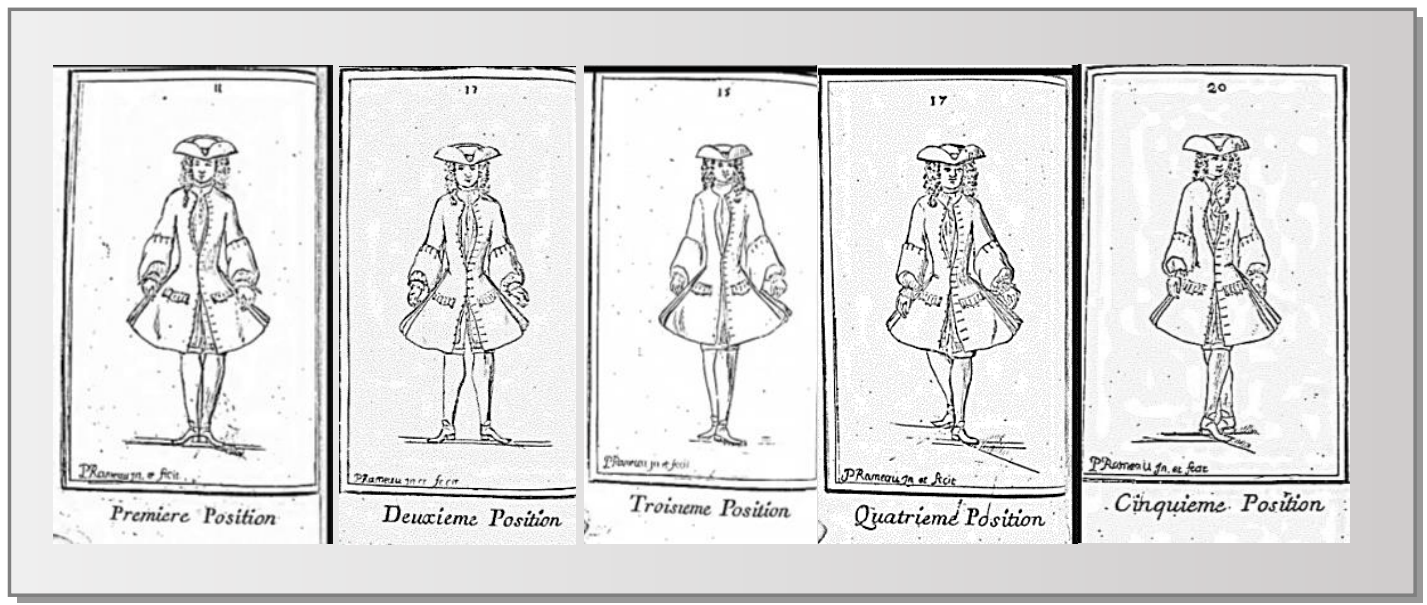

Figura 1

Posições de pés codificadas por Pierre Beauchamps e apresentadas no tratado "Le Maître a Danseur", de Pierre Rameau. Da esquerda para direita: primeira, segunda, terceira, quarta e quinta posições de pés (RAMEAU, 1725)

Tais posições seriam conhecidas como verdadeiras ou nobres, quando os pés estivessem rotacionados para fora a cerca de 45 graus. Em contraponto às posições verdadeiras havia também as falsas posições, quando os pés eram direcionados desajeitadamente para dentro para representar personagens, como marinheiros, bêbados e camponeses.

Nos palcos, as posições dos pés distinguiriam a nobreza da figura do aldeão, e, cenicamente, refletiriam a separação que a nobreza gostaria de continuar a manter diante de indivíduos que não frequentassem a corte. Com relação à codificação das colocações dos pés, Noverre não poupou críticas à relação estabelecida entre os intérpretes de dança e o uso das cinco posições, quando declara:

Quanto às posições, todos sabem que existem cinco. Há mesmo os que entendem que existam dez, divididas de forma assaz singular em boas e más, em verdadeiras e falsas. De fato, o número delas não muda em nada

LOURENÇO, Robson; VITIELLO, Júlia Ziviani. Contraponto em reflexão sobre a prática do balé: escavando camadas ósseas para a observação do mestre de dança através das cartas de JeanGeorges Noverre. Revista da FUNDARTE, Montenegro, p.484-504, ano 19, nº 37, Janeiro/Março. Disponível em: http://seer.fundarte.rs.gov.br/index.php/RevistadaFundarte/index> 30 de março de 2019. 


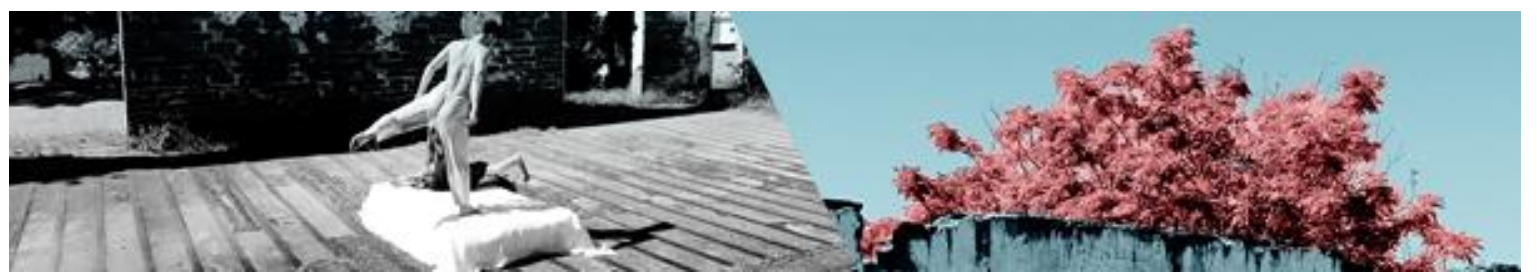

a questão, por isso não as contestarei; direi simplesmente que é bom conhecer as posições, mas melhor esquecê-las. (NOVERRE in MONTEIRO 1998, p. 303).

No entanto, a crítica de Noverre em relação à rotação dos pés não se estabelece apenas sob o ponto de vista de uma codificação recém-estabelecida. Em seu conjunto de cartas de 1760, o mestre de dança francês aprofunda as relações entre o intérprete de dança e as posições de balé, quando reflete que reconheceria qualquer posição do corpo, desde que ele se estabelecesse de modo firme e bem desenhado, pois, sobre as posições, Noverre reflete que:

A arte do grande bailarino consiste exatamente em afastar-se delas e ainda assim agradar. De resto, são excelentes todas as posições em que o corpo fique firme e bem desenhado. Só reconheço as más posições num corpo mal composto, bambo, sem a sustentação das pernas. (NOVERRE in MONTEIRO, 1998, p. 303).

A rotação externa traria para o corpo do intérprete de dança daquele período a experiência de um estado diferenciado para o corpo, quando pendula entre o equilíbrio e desequilíbrio. Gostaríamos de refletir sobre o pêndulo equilíbrio/desequilíbrio da rotação externa do balé sob o ponto de vista de Eugênio Barba e Nicolas Savarese (2012). Tais autores nomeiam o equilíbrio proposto por posições de treinamento dentro das artes do corpo como posições que levariam a um equilíbrio "extracotidiano". Sobre essa afirmação, Barba e Savarese refletem que o elemento que aproxima as imagens de atores e dançarinos de épocas distintas:

[...] é o abandono das posições típicas de um equilíbrio cotidiano a favor de um equilíbrio precário ou extracotidiano. A busca de um equilíbrio extracotidiano exige um esforço físico maior: mas é a partir desse esforço que as tensões do corpo se dilatam e o corpo do ator nos parece vivo antes mesmo que ele comece a se expressar. (BARBA/SAVARESE, 2012, p. 92).

No caso da dança cênica estabelecida na França, as posições em rotação externa dos pés exigiram um novo estado muscular daquele bailarino em sua relação com a gravidade, quando colocariam o intérprete de dança em um equilíbrio permanentemente instável. Segundo Barba e Savarese, a posição em rotação externa criaria tensões que dilatariam a presença do corpo do intérprete de dança

LOURENÇO, Robson; VITIELLO, Júlia Ziviani. Contraponto em reflexão sobre a prática do balé: escavando camadas ósseas para a observação do mestre de dança através das cartas de JeanGeorges Noverre. Revista da FUNDARTE, Montenegro, p.484-504, ano 19, ํㅜ 37, Janeiro/Março. Disponível em: http://.seer.fundarte.rs.gov.br/index.php/RevistadaFundarte/index> 30 de março de 2019. 


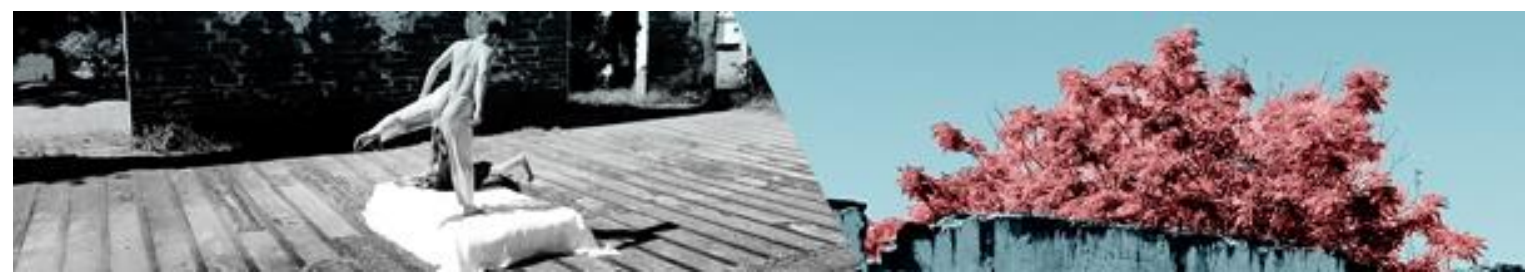

que se preparasse a partir de procedimentos de balé. Sobre essa técnica corporal, os autores refletem sobre suas codificações de equilíbrio, quando:

[...] há uma espécie de intenção que obriga o dançarino a se mover em um equilíbrio precário desde as posições de base. Essa intenção aparece claramente no esquema de movimentos como os arabesques ou attitudes, nos quais todo o peso do corpo se apoia sobre uma única perna, na maioria das vezes, inclusive, sobre a ponta dos pés. Um dos movimentos mais importantes do balé, o plié, consiste em dançar com os joelhos dobrados, a posição ótima de partida para uma pirueta ou um salto. (BARBA/SAVARESE, 2012, p.95).

Atualmente o grau de rotação externa solicitada para os pés dos intérpretes em uma aula de balé é cerca de $180^{\circ}$ em todas nas cinco posições do balé. Isto traz uma polaridade conflituosa na preparação corporal dentro de uma aula de balé, pois ao mesmo tempo que essas posições (feitas com esse grau de amplitude) estabelecem uma característica de equilíbrio instável e auxiliam, eventualmente, a construir a presença do intérprete dentro de sua preparação para a cena, por outro lado também acarretam uma ultrapassagem dos limites corporais dos bailarinos em formação, trazendo um desalinhamento que leva muitos anos para ser recuperado.

A partir dessa polaridade entre precariedade de equilíbrio e as tensões musculares que auxiliariam a construção da presença do corpo do intérprete para a cena, gostaria de levantar algumas questões: quando a abertura dos pés a $180^{\circ}$ começou a ser solicitada? Haveria documentos onde a o aumento de amplitude da rotação dos pés pudesse ser observado? O que isto acarretaria para o alinhamento do corpo naquele ambiente em que atuava Noverre como artista da dança? Quais foram as reflexões desse mestre de dança francês sobre a relação entre o equilíbrio e a rotação dos pés?

A partir dessas perguntas, gostaríamos de refletir como o grau de amplitude da rotação externa dos pés ampliou-se gradualmente na codificação da dança cênica realizada na França a partir do século XVI até o século XIX. Há uma comparação dentro da obra de Marianna Monteiro, quando apresenta a rotação da colocação de pés em dois tratados de épocas diferentes.

LOURENÇO, Robson; VITIELLO, Júlia Ziviani. Contraponto em reflexão sobre a prática do balé: escavando camadas ósseas para a observação do mestre de dança através das cartas de JeanGeorges Noverre. Revista da FUNDARTE, Montenegro, p.484-504, ano 19, ํo 37, Janeiro/Março. Disponível em: http://.seer.fundarte.rs.gov.br/index.php/RevistadaFundarte/index $>30$ de março de 2019. 


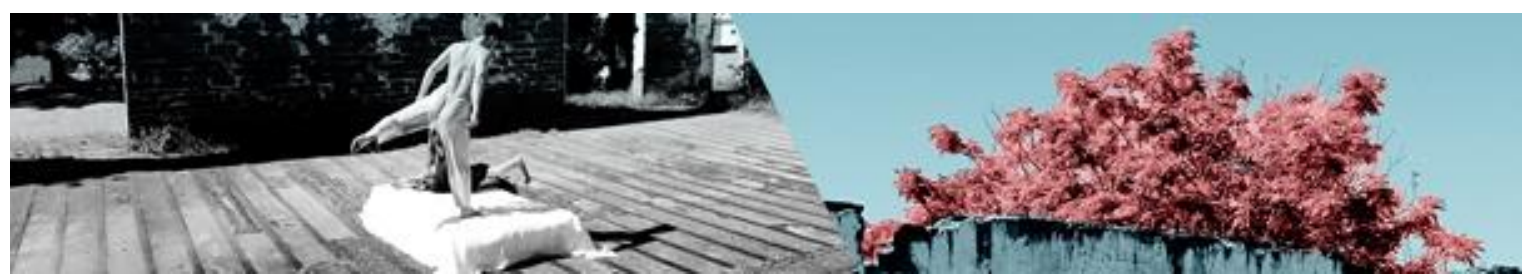

Apresentamos a seguir dois conjuntos de ilustrações. À esquerda há o tratado Antoine Arbeau (de 1588) e o de Pierre Rameau, publicado em 1725.
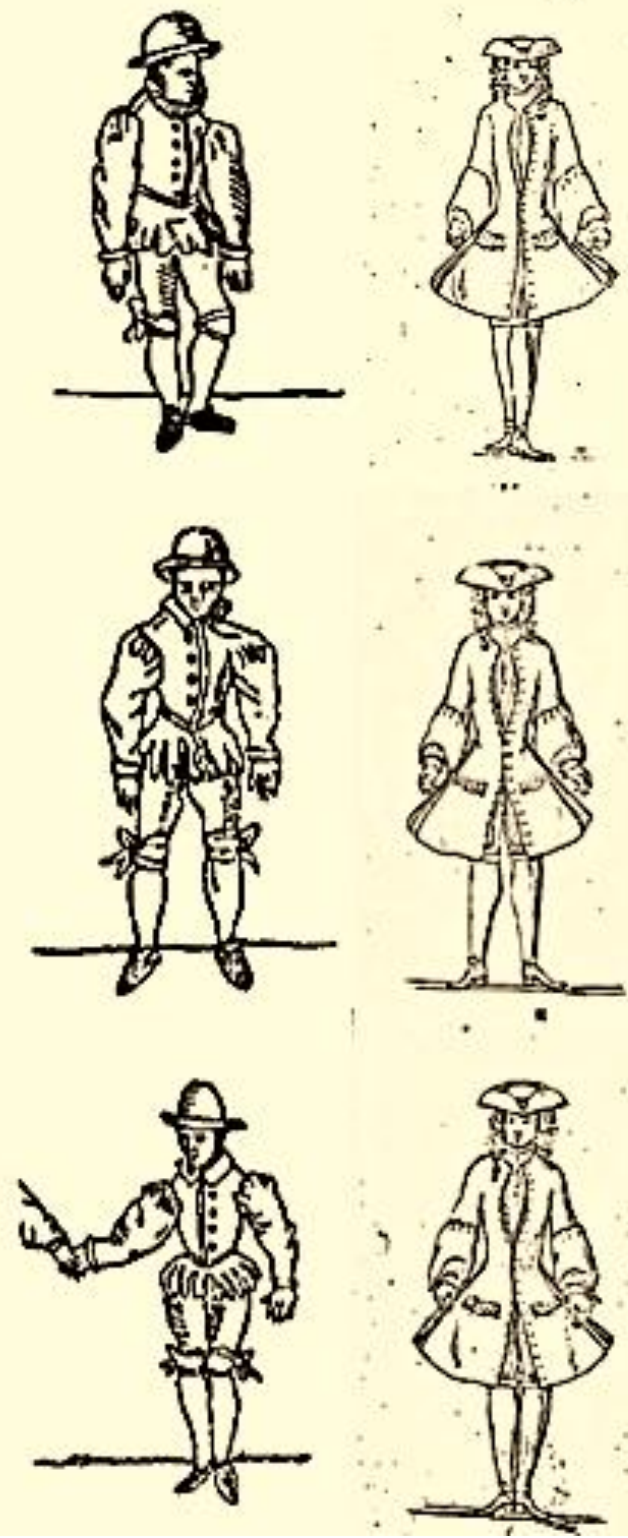

Figura 2

Amplitude da rotação externa dos pés em 1588 e 1725. llustração dos tratados de dança de Thoinot Arbeau e Pierre Rameau (MONTEIRO, 1998, p. 167)

LOURENÇO, Robson; VITIELLO, Júlia Ziviani. Contraponto em reflexão sobre a prática do balé: escavando camadas ósseas para a observação do mestre de dança através das cartas de JeanGeorges Noverre. Revista da FUNDARTE, Montenegro, p.484-504, ano 19, ํㅜ 37, Janeiro/Março. Disponível em: http://.seer.fundarte.rs.gov.br/index.php/RevistadaFundarte/index> 30 de março de 2019. 


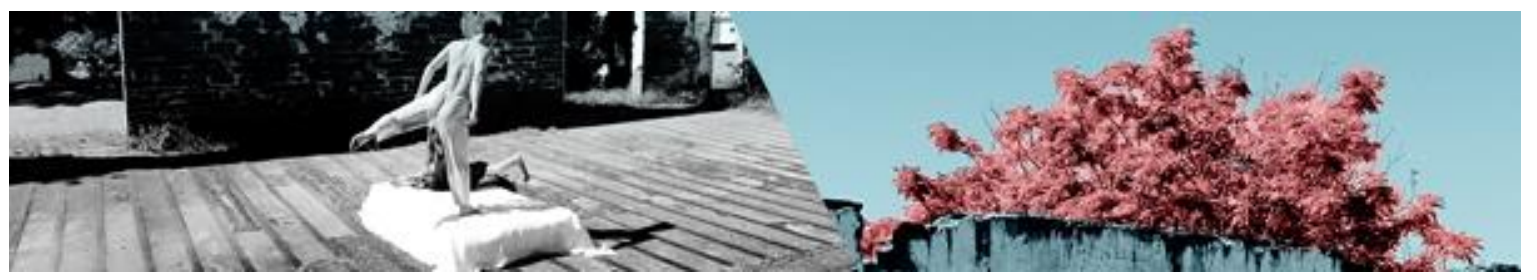

Ao observar as ilustrações da figura 2 percebe-se que em cerca de cento e trinta anos a rotação externa ampliou-se consideravelmente. Além disso, nota-se que há diferenças da flexão da articulação dos joelhos nas duas séries de desenhos, com a ilustração de Rameau (à direita) delineando um intérprete com estas articulações mais estendidas.

Após o tratado de Rameau, de 1725, a rotação externa seria ainda mais ampliada ao longo do século XVIII e XIX, dentro do treinamento proposto pelo mestre de dança Auguste Vestris ${ }^{4}$, que exigiria de seus alunos que atingissem os 180 (HOMANS, 2012, p. 159) na amplitude da rotação dos pés em relação ao chão, o que é solicitado atualmente nas aulas de balé.

Jean-Georges Noverre, ao perceber as alterações graduais ocorridas no grau de rotação externa durante as aulas de dança no período em que atuava como artista, solicitava aos professores que estivessem atentos a seus alunos. Em suas cartas, o artista francês levantou questões em relação ao direcionamento os movimentos dos intérpretes dentro das aulas de dança, quando os pés alicerçariam a base de todo o corpo, pois:

\begin{abstract}
A planta do pé é a verdadeira base sobre a qual repousa inteira nossa máquina. Um escultor correria o risco de perder sua obra se a apoiasse sobre algo redondo e imóvel. A queda da estátua seria inevitável, romperse-ia, espatifar-se-ia necessariamente. $O$ bailarino, pela mesma razão, deve servir-se de todos os dedos de seus pés, bem como de ramos, que ao espalharem-se no solo, aumentam a superfície de apoio, dão firmeza e mantêm o corpo em equilíbrio justo e conveniente. (NOVERRE in MONTEIRO, 1998, p. 326).
\end{abstract}

No trecho acima destacado na obra de Noverre, chama a atenção a percepção desse artista ao relacionar a planta dos pés com o equilíbrio do restante do corpo. Noverre aponta que o equilíbrio justo e conveniente é um reflexo do ato de espalhar os dedos dos pés no chão, o que aumentaria a superfície de apoio. Se

\footnotetext{
${ }^{4}$ Auguste Vestris (1760-1842) - Integrante de uma família de bailarinos, estreou como intérprete em 1772 e tornou-se solista da Ópera de Paris em 1776. Dois anos mais tarde se tornaria o primeiro bailarino dessa casa de espetáculos e "etóile" em 1780. Durante a Revolução Francesa fugiu para Londres, voltando a dançar na Ópera em 1793 até o final de sua carreira em 1815. Tornou-se um dos grandes professores de seu tempo e entre seus alunos estiveram Didelot, Perrot, Bournoville e Marie Taglioni. (FARO, 1989, p. 404).
}

LOURENÇO, Robson; VITIELLO, Júlia Ziviani. Contraponto em reflexão sobre a prática do balé: escavando camadas ósseas para a observação do mestre de dança através das cartas de JeanGeorges Noverre. Revista da FUNDARTE, Montenegro, p.484-504, ano 19, ํo 37, Janeiro/Março. Disponível em: http://.seer.fundarte.rs.gov.br/index.php/RevistadaFundarte/index> 30 de março de 2019. 


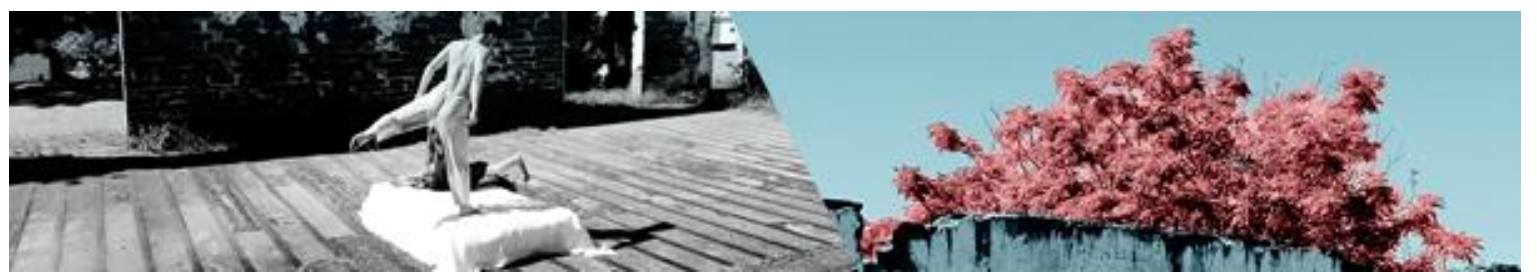

houvesse negligência do intérprete em alongar os dedos dos pés e ele não perceber a superfície de apoio haveria acidentes, quando:

O pé perderá sua forma natural, arredondar-se-á e vacilará para os lados, sem parar, do dedinho para o dedão, do dedão para o dedinho. Essa espécie de balanço, ocasionada pela forma convexa tomada pela extremidade dos pés nessa posição, opõe-se a toda e qualquer estabilidade. Os tornozelos vacilam e deslocam-se. (idem, p. 326).

Através dos pés, Noverre busca a estabilidade do corpo do bailarino dentro de um pensamento que se propõe a relacionar a percepção dos pés e o equilíbrio do corpo como um todo. Há no pensamento de Noverre uma relação entre o que é desenvolvido no período da preparação de um intérprete de dança do século XVIII e o que seria apresentado em cena, quando reflete sobre o retorno do salto:

No momento em que a massa cair de uma certa altura, sem encontrar na base um ponto fixo capaz de recebê-la e de finalizar a queda, todas as articulações ficarão feridas com o choque, com o abalo e no instante em que o bailarino procurasse uma posição firme, no auge do esforço para fugir do perigo, sucumbiria, seja na sequência de uma entorse ou da ruptura de uma perna ou do tendão. A passagem rápida do relaxamento à forte tensão, da flexão à extensão violenta é, pois, ocasião de uma série de acidentes que, sem dúvida, seriam menos frequentes se, de alguma forma, nos resignássemos à queda, sem que as partes fracas tentassem resistir contra um peso que não podem vencer nem sustentar. (NOVERRE in MONTEIRO, 1998, p. 326).

Mais adiante, nas cartas de 1760, Noverre reflete sobre qual seria a responsabilidade de um intérprete de dança para evitar as lesões decorrentes do seu trabalho como bailarino:

As quedas ocasionadas pelas irregularidades do teatro e outras coisas similares não são atribuíveis à nossa imperícia, mas as que provêm de nossas fraquezas e do desgaste decorrente de um excesso de trabalho, e as que acompanham um gênero de vida que conduz ao esgotamento, só uma mudança de conduta e a busca de uma atuação proporcional de forças que nos restam podem preveni-las. (NOVERRE in MONTEIRO, 1998, p. 326-7).

LOURENÇO, Robson; VITIELLO, Júlia Ziviani. Contraponto em reflexão sobre a prática do balé: escavando camadas ósseas para a observação do mestre de dança através das cartas de JeanGeorges Noverre. Revista da FUNDARTE, Montenegro, p.484-504, ano 19, ํㅜ 37, Janeiro/Março. Disponível em: http://seer.fundarte.rs.gov.br/index.php/RevistadaFundarte/index> 30 de março de 2019. 


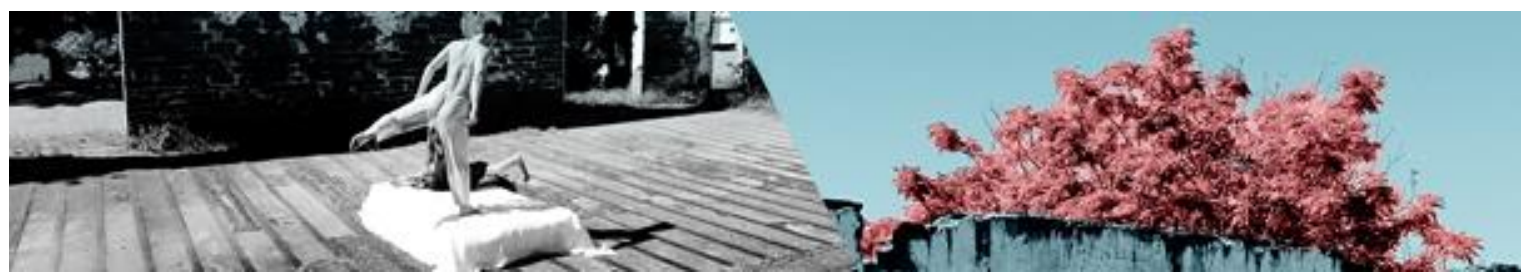

No conjunto de cartas escritos em 1760, um trecho foi destacado para esse artigo, para aprofundar a proposição de como Noverre evitaria o desgaste decorrente do excesso de trabalho de um bailarino, e como preveniria eventuais lesões. Na carta de número doze, o mestre de balé francês aponta o equívoco da percepção da rotação dos pés durante o estudo do balé. Neste trecho Noverre critica que "A maior parte dos jovens que se dedicam à dança se persuade de que conseguirão a rotação forçando unicamente os pés para fora" (idem, 1998, p. 323).

Para o mestre de dança francês, a rotação externa a partir dos pés é um "método um tanto quanto falho, já que desloca o tornozelo sem atuar sobre os joelhos ou sobre as coxas" (idem). Nesse trecho, Noverre prima pela rotação externa a partir de uma percepção total dos membros inferiores, quando haveria um alinhamento conjunto das articulações dos pés com a dos joelhos. Sobre a origem da rotação externa e sua relação com a articulação existente entre os ossos do fêmur e da tíbia, Noverre reflete:

O joelho, com efeito, só tem dois movimentos: de flexão e de extensão; um determina que a perna vá para trás, outro para a frente; ele não se transporta en dehors ou en dedans; tudo depende da coxa, já que ela comanda soberana as partes que são inferiores. Ela as gira como consequência do movimento de rotação de que está dotada, e qualquer que seja a direção para onde se volte, o joelho, a perna e o pé são forçados a segui-la. (ibidem).

O primeiro conjunto de cartas de Noverre foi escrito há cerca de 250 anos e, nesse documento, esse artista e pesquisador da dança aponta que há um erro de percepção de professores e estudantes, de que a rotação seria alcançada, unicamente, forçando os pés para fora (e esse equívoco perpetua-se até os dias atuais).

Para refletir sobre a rotação externa na técnica do balé e aliá-las às reflexões de Jean-Georges Noverre, gostaríamos de aprofundar o contraponto entre passado e presente a partir de alguns apontamentos do artista francês que serão apresentados. Para ilustrar a reflexão, apresentamos a seguir um desenho anatômico desenvolvido pelo primeiro autor deste artigo:

LOURENÇO, Robson; VITIELLO, Júlia Ziviani. Contraponto em reflexão sobre a prática do balé: escavando camadas ósseas para a observação do mestre de dança através das cartas de JeanGeorges Noverre. Revista da FUNDARTE, Montenegro, p.484-504, ano 19, no 37, Janeiro/Março. Disponível em: http://.seer.fundarte.rs.gov.br/index.php/RevistadaFundarte/index> 30 de março de 2019. 

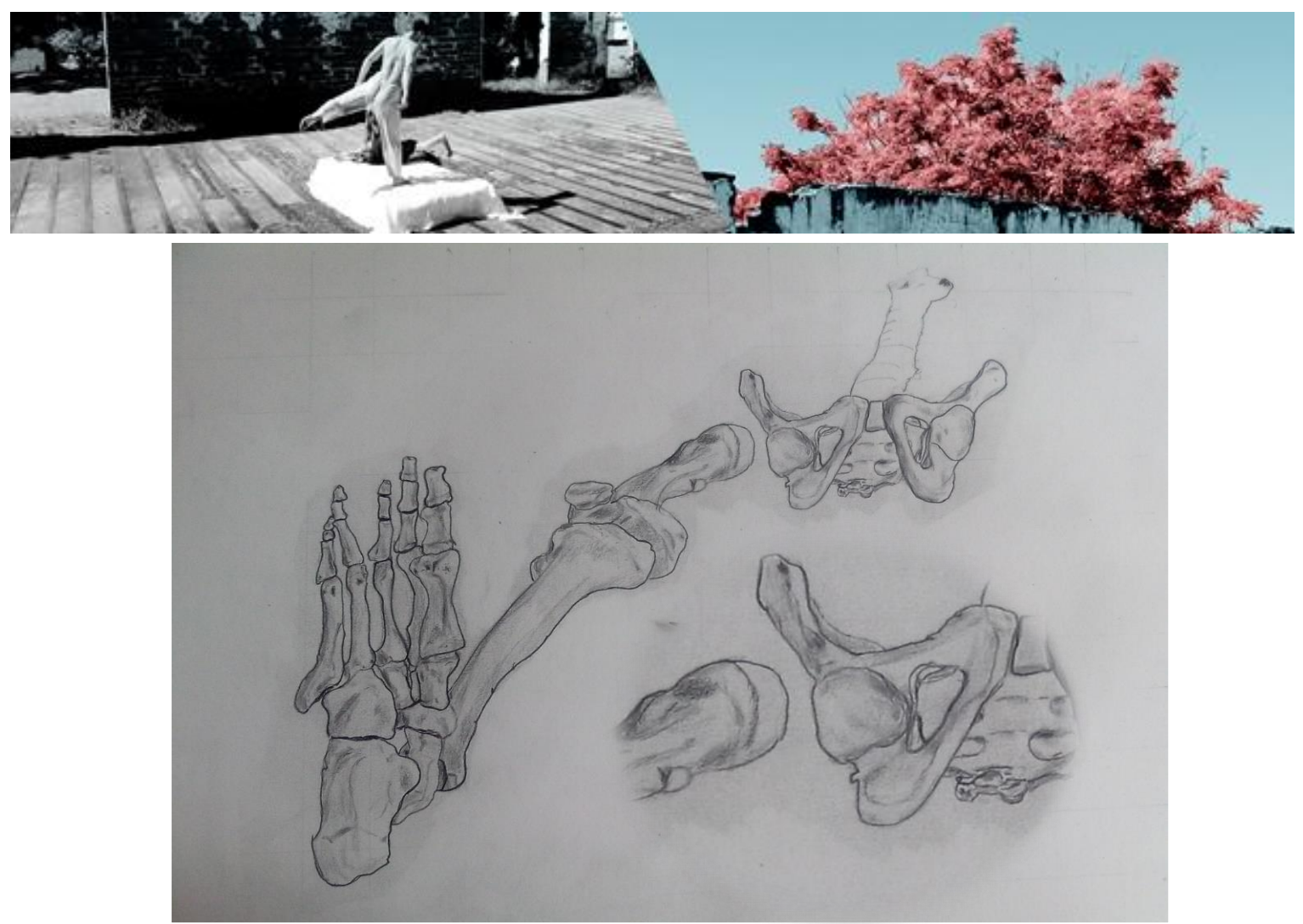

Figura 3

Desenho anatômico realizado dentro da pesquisa da relação entre pelve e pés para desenvolver a perspectiva do chão (Outubro/2014)

Solicitamos aos leitores deste artigo para que percebam as estruturas apresentadas na ilustração anterior, principalmente a relação entre os ossos do fêmur e da pelve. O modelo anatômico foi desenhado de modo a ter um espaço proposital na articulação coxofemoral, com o intuito de refletir, a partir do desenho, sobre um dos pensamentos de Noverre com relação à rotação externa. Dentro de suas cartas, o mestre de dança francês aponta que o principal meio para o bailarino alcançar a rotação externa é:

movendo no sentido de aproveitar a liberdade do movimento de rotação do fêmur na cavidade cotiloide dos ossos da rotação externa das coxas, movendo-as no sentido de aproveitar a liberdade do movimento de rotação do fêmur na cavidade cotiloide dos ossos do quadril. (NOVERRE in MONTEIRO, 1998, p. 312).

Com o apontamento de Noverre desenvolvido no trecho de sua carta de 1760, o mestre de dança francês transfere a origem da rotação externa dos pés para a estrutura da pelve. Além disso, observa-se nessa reflexão que Noverre tinha domínio das nomenclaturas das estruturas ósseas do corpo humano e também entrelaçou saberes, ao relacionar em seus escritos, o conhecimento no campo da escavando camadas ósseas para a observação do mestre de dança através das cartas de JeanGeorges Noverre. Revista da FUNDARTE, Montenegro, p.484-504, ano 19, ํㅜ 37, Janeiro/Março. Disponível em: http://.seer.fundarte.rs.gov.br/index.php/RevistadaFundarte/index> 30 de março de 2019. 


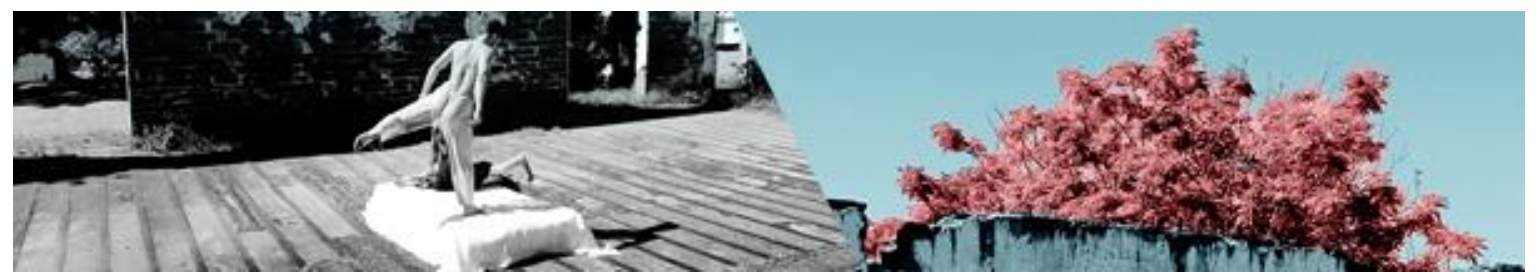

Anatomia aos da dança cênica praticada naquele momento.

Os estudos osteológicos fizeram com que Noverre refletisse que alguns procedimentos dentro de uma aula de balé, como ronds de jambes en dedans ou en dehors e os battements tendus bastariam para aprimorar a rotação externa a partir da cavidade do fêmur. Para o mestre de dança francês seria necessário apenas o exercício moderado e contínuo de tais movimentos que "pouco a pouco garantem a mobilidade, impulso e flexibilidade" (NOVERRE in MONTEIRO, 1998, p. 323) e que são utilizados até os dias de hoje nas sequências didáticas dentro de aulas de balé. Mas de onde viriam os conhecimentos anatômicos de Noverre para entrelaçar os conhecimentos da dança com os estudos osteológicos do corpo?

\section{Aliança entre a anatomia e o mestre de dança}

Desde 0 advento do raio-X, das tomografias e das imagens computadorizadas, o imaginário do interior do corpo humano é muito presente dentro da cultura ocidental. No entanto, o conhecimento a respeito do interior do corpo humano na época de Noverre só poderia ser acessado caso o indivíduo comparecesse a sessões de dissecações de cadáveres ou ao estudar tratados anatômicos e, através de suas ilustrações, perceber como seria o funcionamento do interior do corpo humano.

Segundo a autora Susan Foster (1996), a anatomia penetrou nos procedimentos utilizados dentro das salas de dança ao longo do século XVIII. E em alguns ambientes daquele período, o pensamento da anatomia começou a alterar a rotina de treinamentos dos intérpretes daquela época:

Se os dançarinos reuniam esporadicamente o que pudessem sobre técnicas de atuação, havia a busca de uma pedagogia para aprimorar a destreza da dança através de uma clara progressão e a anatomia se tornou uma ferramenta de análise fundamental para entender os problemas físicos dos intérpretes e para orientar a cultura geral do corpo. (FOSTER, 1996, p. 110, tradução nossa).

conhecimento da anatomia fundamentou Jean-Georges Noverre para

LOURENÇO, Robson; VITIELLO, Júlia Ziviani. Contraponto em reflexão sobre a prática do balé: escavando camadas ósseas para a observação do mestre de dança através das cartas de JeanGeorges Noverre. Revista da FUNDARTE, Montenegro, p.484-504, ano 19, nº 37, Janeiro/Março. Disponível em: http://.seer.fundarte.rs.gov.br/index.php/RevistadaFundarte/index> 30 de março de 2019. 


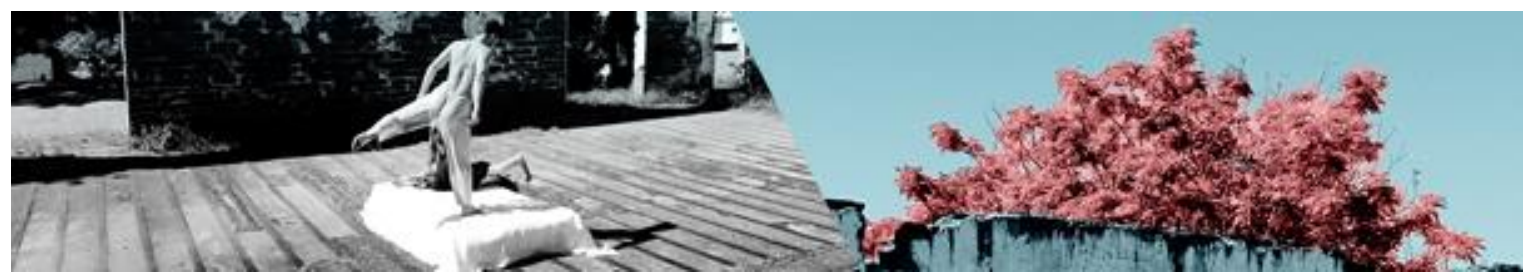

orientar seu olhar para a preparação do corpo da dança cênica desenvolvida no período que atuou como artista. No entanto, quais seriam as fontes de conhecimento para que Noverre desenvolvesse seus entrelaçamentos entre a preparação para a dança e a anatomia humana? A partir destes saberes do interior do corpo, quais seriam os apontamentos em suas cartas para os mestres de dança daquele período? Aos oitenta anos, em suas cartas de 1807, Noverre declara que realizou alguns estudos sobre anatomia ao longo da vida:

\begin{abstract}
Gostaria de acrescentar que eu fiz na minha juventude um curso de osteologia, isto tem sido muito útil nas minhas aulas ou diminuindo o tempo das instruções ou trazendo mais clareza nas demonstrações dos princípios; essa arte desvenda as causas que se opõem a execução dos movimentos, ao conhecer a estrutura óssea do homem, suas alavancas e articulações que operam várias ações, eu não exijo dos meus alunos o que a natureza não queira e eu direciono minhas aulas após examinar a conformação prévia de cada um deles. (NOVERRE, 1807, p. 128, tradução nossa)
\end{abstract}

Não foram encontrados indícios até o momento de que o curso de osteologia que Noverre realizou foi feito com a presença de um professor, ou que teria participado de um curso regular. Até o momento também não foi encontrado nenhum registro em suas cartas (ou nas referências bibliográficas para a elaboração deste artigo), de que Noverre tenha comparecido às sessões de dissecação nos teatros anatômicos franceses daquele período.

No entanto, ao estudar as cartas do mestre de dança francês é possível apontar algumas hipóteses de como se alterou o modo como Noverre relacionava os conhecimentos anatômicos com seus estudos em dança, pois caminhos distintos sobre o campo de saber da anatomia são encontrados no conjunto de cartas de 1760 e de 1807.

No primeiro conjunto de correspondências, Noverre entrelaça as nomenclaturas e conhecimentos anatômicos a outros pensamentos sobre a dança cênica daquele período, reflexo do próprio formato "carta" que imbrica temas e subtemas, como já explicado anteriormente. Em sua primeira obra literária, Noverre compara os conhecimentos necessários a um mestre de dança aos saberes necessários para a formação de um pintor. Para Noverre, esse último profissional: escavando camadas ósseas para a observação do mestre de dança através das cartas de JeanGeorges Noverre. Revista da FUNDARTE, Montenegro, p.484-504, ano 19, ํㅜ 37, Janeiro/Março. Disponível em: http://.seer.fundarte.rs.gov.br/index.php/RevistadaFundarte/index> 30 de março de 2019. 


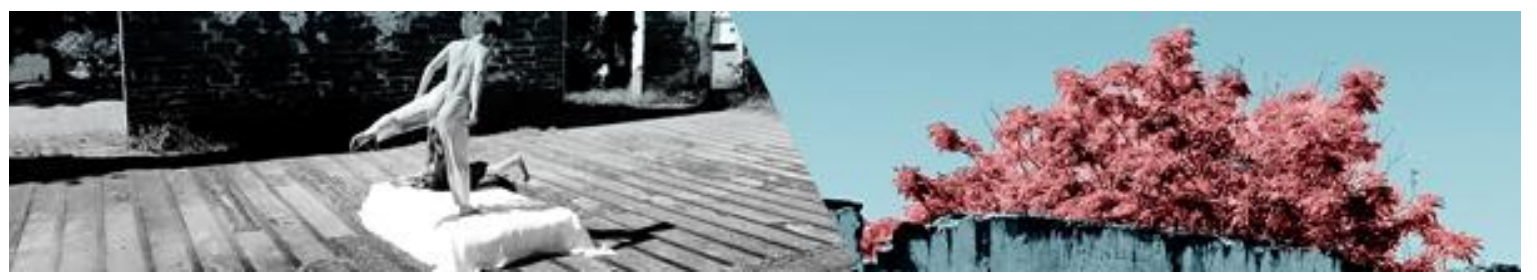

não estuda anatomia para vir a pintar esqueletos, nem desenha a partir do 'esfolado' de Michelangelo visando colocar essas figuras horrendas em seus quadros. Tais estudos, no entanto, lhe são absolutamente úteis para representar o homem em justas proporções, para desenhar suas posturas e sua movimentação. Se o nu deve ser percebido sob o panejamento, é preciso que se sintam também os ossos sob as carnes. É essencial discernir cada coisa em seu lugar: o ser humano sob as roupagens, o descarnado sob a pele, o esqueleto sob as carnes. (NOVERRRE in MONTEIRO, 1998, p. 312).

No discurso de Noverre em 1760, o autor apresenta a relevância do estudo da anatomia dentro da formação dos pintores. Já no conjunto de cartas de 1807 , Noverre aprofunda os seus estudos anatômicos e questiona mais diretamente a necessidade do conhecimento da anatomia por parte dos mestres de dança do período, quando questiona: "Não haveria necessidade dos mestres de dança, a exemplo dos pintores, terem um conhecimento, que não seja em sua perfeição, mas pelo menos geral da anatomia? " (NOVERRE, 1807, p. 192 [tradução nossa]).

A relevância que Noverre traz para o estudo da anatomia na formação do professor de dança é ampliada no conjunto de cartas de 1807 , em relação àquelas que foram escritas em 1760. O artista francês dedicou em sua primeira obra literária apenas alguns apontamentos anatômicos e somente em duas cartas. Já no início do século XIX, Noverre dedica um capítulo inteiro ao estudo da anatomia, cuja tradução para o português é intitulada como "Dos conhecimentos necessários ao mestre de dança"5.

Nos primeiros anos de 1800, Noverre revela quais seriam suas intenções com esse estudo e aponta como linha-mestra de suas reflexões o foco nas articulações do corpo humano:

Meu plano não é, no entanto, realizar ou desenvolver uma dissertação anatômica, que me trouxesse um ar de demonstrador e que me entendessem erroneamente; Só descreverei como as articulações colaboram para os movimentos de um bailarino. Este conhecimento é particularmente útil à beleza e à harmonia na dança, cujas fontes dependem do jogo flexível e primordial das articulações e determinam as atitudes do corpo, os movimentos das pernas, e o desenvolvimento dos braços. Sem as articulações, nada é possível de ser realizado dentro da arte da dança: a

\footnotetext{
${ }^{5}$ A carta estudada para a reflexão deste artigo é a missiva de número treze da edição de 1807, cujo nome em original é "Des Connoissances d'Anatomie nécessaires au maître de Ballets".
}

LOURENÇO, Robson; VITIELLO, Júlia Ziviani. Contraponto em reflexão sobre a prática do balé: escavando camadas ósseas para a observação do mestre de dança através das cartas de JeanGeorges Noverre. Revista da FUNDARTE, Montenegro, p.484-504, ano 19, ํㅜ 37, Janeiro/Março. Disponível em: http://.seer.fundarte.rs.gov.br/index.php/RevistadaFundarte/index> 30 de março de 2019. 


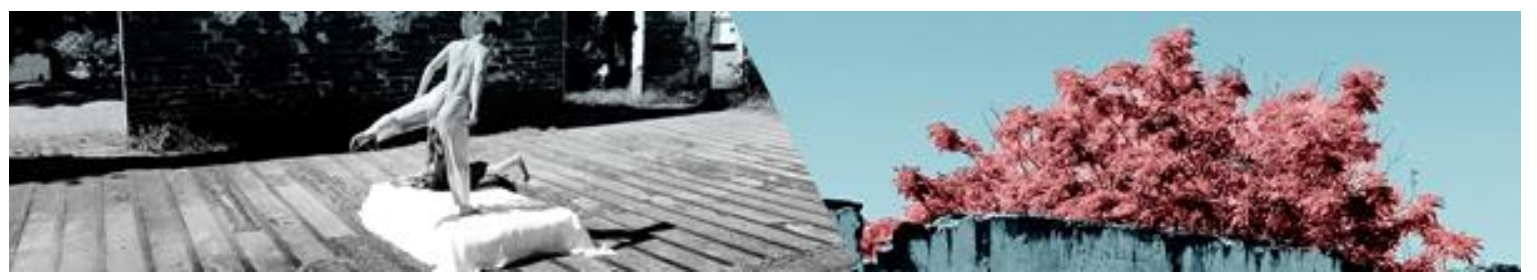

cabeça sobretudo, não pode ter curvaturas e se contrastar agradavelmente com as posições do corpo, então o estudo desta união e desta harmonia constituem a dança por excelência; é nesta união que será fornecido àquela arte a segurança e os recursos que foram esquecidos até este momento, porque o artista não consegue vislumbrar este objetivo, nem compreender a extensão desta carreira, a não ser que consiga perceber seus princípios e mergulhar em regras naturais que até o presente momento, são vagas e incertas. (NOVERRE, 1807, p. 169-170, tradução nossa).

A pesquisadora brasileira Mariana Monteiro ressalta que a integração entre o conhecimento do interior do corpo humano e o balé dentro da obra de Noverre "é posto a serviço da dança, como um dos estudos necessários ao mestre de balé, para que o trabalho corporal do bailarino se assente sobre bases racionais" (MONTEIRO, 1998, p. 148). A partir do pensamento de Monteiro, algumas questões poderiam ser levantadas: quais seriam as fontes de pesquisa de Jean-Georges Noverre para que desenvolvesse as bases racionais para o desenvolvimento da arte da dança naquele período? Além da anatomia, quais seriam as outras plataformas de conhecimento que influenciariam a obra de Noverre a respeito do estudo do movimento e sua integração com o estudo do balé naquele período?

No segundo conjunto de cartas de 1807, Noverre cita claramente quais são os autores por ele estudados, quando aconselha ao leitor a "consultar o esqueleto com Winslow, avaliar a força muscular com Borelli ou estudar o mecanismo animal na obra do famoso Barthès" (NOVERRE, 1807, p. 186 [tradução nossa]). O estudo das estruturas ósseas de Noverre parte do pensamento do anatomista dinamarquês Jacob B. Winslow (1776), que atuou na França na passagem do século XVIII para o XIX e desenvolveu um estudo minucioso das inserções musculares e articulares do corpo. Winslow é reconhecido pela minúcia com que apresenta as estruturas anatômicas da região dos ombros até a face no tratado "Exposition anatomique de la structure du corps humanis".

Outro autor citado por Noverre é Johanni Alphonsi Borelli, um físico e fisiologista italiano que publicou o tratado "De motu animalium" em 1680, cujo conteúdo descrevia as funções das alavancas do sistema músculo-esquelético do corpo humano, com isto foi possível perceber que tais estruturas ampliariam a percepção do corpo humano em movimento, principalmente na relação com as

LOURENÇO, Robson; VITIELLO, Júlia Ziviani. Contraponto em reflexão sobre a prática do balé: escavando camadas ósseas para a observação do mestre de dança através das cartas de JeanGeorges Noverre. Revista da FUNDARTE, Montenegro, p.484-504, ano 19, ํㅜ 37, Janeiro/Março.

Disponível em: http://seer.fundarte.rs.gov.br/index.php/RevistadaFundarte/index> 30 de março de 2019. 


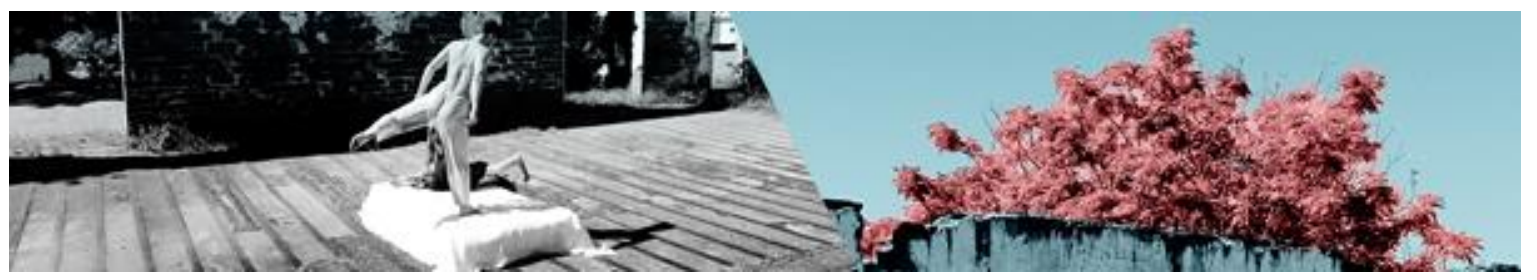

linhas de gravidade. Tal estudo de Borelli inaugurou o nascente campo de conhecimento da mecânica do movimento.

Além de Winslow e Borelli, o médico e enciclopedista francês Paul Joseph Barthès (1734-1806) também é citado no conjunto de cartas de Noverre de 1807. Barthès escreveu tratados que entrelaçavam a anatomia à mecânica do movimento. Entre suas obras podemos destacar "Nouvelle Méchanique des Mouvement de l'homme et des animaux", de $1798^{6}$, quando analisa a progressão da marcha humana através da comparação entre os movimentos dos homens e dos animais. Para Barthès "o Homem é naturalmente quadrúpede durante a infância" (BARTHES, 1798, p. 231 [tradução nossa]) e adquire o movimento como bípede ao longo dos primeiros momentos de sua vida. Nesse tratado, Barthès faz uma longa exposição anatômica e cinesiológica do caminhar humano e estuda a marcha a partir da relação que Giovanni Borelli estabelece entre os apoios e alavancas dos ossos.

Para aprofundarmos os estudos anatômicos de Noverre, apresentaremos abaixo duas ilustrações.

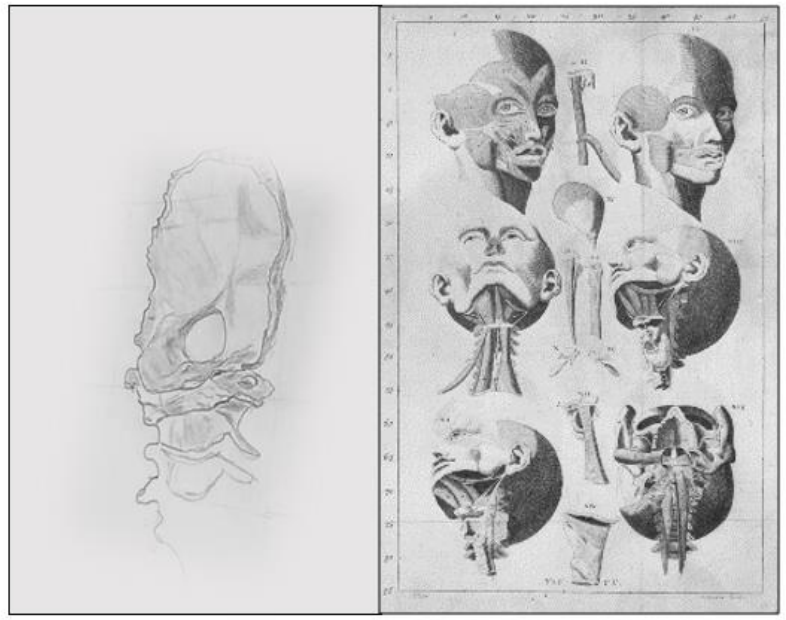

Figura 4

À esquerda desenho à lápis desenvolvido pelo primeiro autor da pesquisa da estrutura do occipital em conjunto com a primeira vértebra cervical. À direita anatomia osteomuscular do rosto llustrações anatômicas da obra de Jacob B. Winslow. (WINSLOW, 1776, p. 716)

\footnotetext{
${ }^{6}$ A edição da obra 1798, de Paul Joseph Barthès é uma reedição do seu ensaio de 1782.
}

LOURENÇO, Robson; VITIELLO, Júlia Ziviani. Contraponto em reflexão sobre a prática do balé: escavando camadas ósseas para a observação do mestre de dança através das cartas de JeanGeorges Noverre. Revista da FUNDARTE, Montenegro, p.484-504, ano 19, nำ37, Janeiro/Março. Disponível em: http://.seer.fundarte.rs.gov.br/index.php/RevistadaFundarte/index $>30$ de março de 2019. 


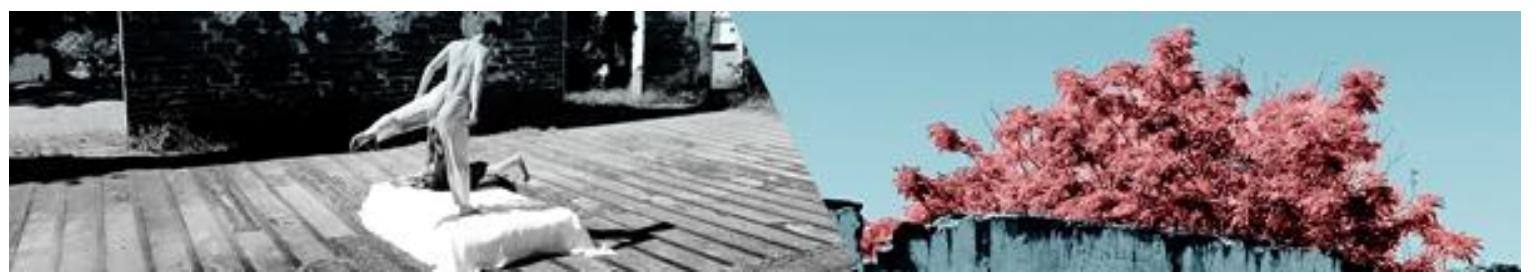

Na figura anterior, à esquerda está um dos desenhos desenvolvidos para esta pesquisa, que representa a estrutura nomeada como occipital e também as três primeiras vértebras cervicais. À direita há uma ilustração da obra "Exposition anatomique de la structure du corps humanis", de Winslow (1776).

As ilustrações apresentadas anteriormente têm o objetivo de criar uma base imagética para o pensamento de Jean-Georges Noverre a respeito dos possíveis movimentos do crânio e das musculaturas do rosto. Convidamos as leitoras e leitores a mirarem ambas as ilustrações, em conjunto com as palavras desenvolvidas por Noverre, sobre o posicionamento da cabeça dentro do treinamento em dança naquele período:

As posições da cabeça contrastam com o busto e suas oposições trazem um dos maiores prazeres dentro da dança. A cabeça dá valor a todas as atitudes de elegância em todas as posições; e dá vida e alma a cada movimento do corpo, se ela não trabalha com graça e não contrasta com o gosto e tudo está morto. (NOVERRE, 1807, 176, tradução nossa).

Mais adiante, Noverre penetra sua observação para o conjunto osteológico das primeiras vértebras e faz uma descrição detalhada das articulações que movem o crânio:

A articulação que coopera com o movimento da cabeça em todas as posições é chamada de pivô. A articulação é considerada como pivô, quando um osso gira sobre outro, que é o que ocorre com o movimento da cabeça por meio da apófise odontóide da segunda vértebra cervical [...] estes movimentos são modificados infinitamente e de acordo com a vontade do homem. (idem, 177, tradução nossa).

Em um trecho posterior, Noverre descreve a musculatura que envolve a região das vértebras cervicais, quando reflete sobre as contrações e relaxamentos dos feixes musculares que envolvem esta região. Além disso, apresenta como a percepção desta parte do corpo poderia relacionar-se com a busca pela interpretação expressiva. Segundo Noverre:

LOURENÇO, Robson; VITIELLO, Júlia Ziviani. Contraponto em reflexão sobre a prática do balé: escavando camadas ósseas para a observação do mestre de dança através das cartas de JeanGeorges Noverre. Revista da FUNDARTE, Montenegro, p.484-504, ano 19, ํㅜ 37, Janeiro/Março. Disponível em: http://seer.fundarte.rs.gov.br/index.php/RevistadaFundarte/index> 30 de março de 2019. 


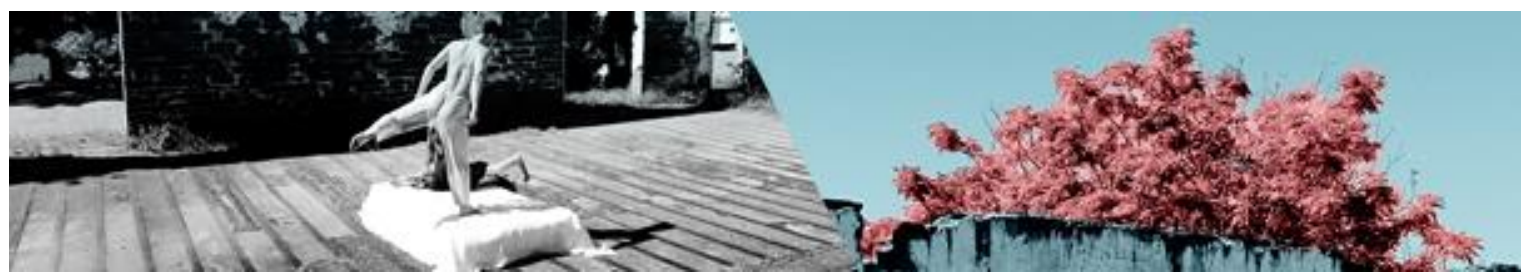

A ação simultânea destes músculos produz a imobilidade da cabeça no medo ou no terror; suas contrações espasmódicas ou desordenadas determinam o contrário e estes movimentos convulsivos ocorrem em ações arriscadas, em estado de cólera, etc. O estado de imobilidade está sempre ligada à expressão da face no espanto ou no medo, já o espasmo destes músculos está ligado ao distúrbio e à fúria. (NOVERRE, 1807, p. 178, tradução nossa).

Apreendidos a partir da obra de Jacob Winslow, Noverre integra os estudos anatômicos da musculatura que envolve a coluna cervical, com o intuito de analisar as possibilidades das mobilizações expressivas da face. Segundo o artista francês, o estudo minucioso da contração e do relaxamento das musculaturas que envolvem a garganta, construiria um caminho para um mestre de dança direcionar a preparação do intérprete para o palco. O escavar anatômico dentro das cartas de Noverre traz à tona a estruturas e feixes musculares do pescoço, e os alia às possíveis capacidades expressivas do rosto, da garganta e da região próxima aos ombros. Habilidades que poderiam ser percebidas pelo intérprete e serem utilizadas futuramente em ensaios e dentro da cena.

\section{Considerações finais - eterno revolver}

Revolver as reflexões anatômicas de Jean-Georges Noverre apresenta uma oportunidade para desenvolver um encontro entre passado-presente no universo de ensino da técnica do balé. Em muitos contextos no Brasil, o ensino de balé ainda acontece de forma rígida e imposta externamente, quando as especificidades de cada aluno são desconsideradas. Tais contextos muitas vezes alicerçam a hipótese de que tal transmissão é desenvolvida por esse caminho pelos mediadores de conhecimento em dança, porque tais professores também receberam o conhecimento imposto externamente, sem questionarem a aprendizagem proposta por seus docentes anteriormente.

Especificamente nas aulas de balé, há muitos professores que desenvolvem a preparação de seus alunos em encaminhamentos que não respeitam os limites anatômicos dos discentes. Muitas vezes tais docentes não estimulam o 2019. 


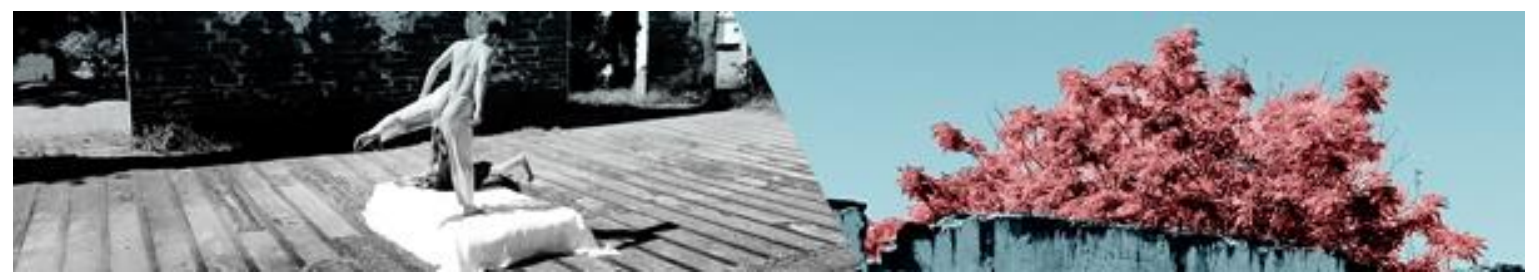

intérprete em formação a refletir sobre o modo como está fazendo determinado movimento. Em muitos casos tal fato também ocorre em aulas de companhias profissionais de dança, aonde há a preparação corporal dos intérpretes através de aulas de balé.

Ao não ser estimulado pelo mediador de uma aula de técnica de dança, o estudante ou profissional de dança associa o ato de "como fazer" determinado movimento a "o que fazer", muitas vezes em nome de uma tradição que é passada corporalmente ao longo das gerações.

Os escritos de Noverre, ao entrelaçarem a anatomia com o estudo do balé, nos aponta que talvez os saberes anatômicos possam embasar rastros de tradição, que talvez tenham caído em esquecimento nas salas de aula e de ensaio. Ao revolver os escritos de Noverre, constrói-se uma narrativa anatômica para compreender "como" o movimento do balé pode ser realizado para potencializar, ainda mais, "o que fazer".

\section{Referências :}

BARTHÈS, Paul Joseph. Nouvelle Méchanique des Mouvements de L'Homme et des Animaux. Acesso através do site da Bibliothèque Interuniversitaire de Santé. Acesso em 12.10.2015, às 10h33min, através do endereço eletrônico: http://www.biusante.parisdescartes.fr/histoire/medica/resultats/index.php?cote=06762 $\underline{\text { \&do=chapitre. }}$ Paris: A Carcassone, de l'impremierie de Pierre Polese, 1798.

FARO, Antonio José / SAMPAIO, Luiz Paulo. Dicionário de balé e dança. 1a. Edição. Jorge Zahar Editor: Rio de Janeiro, 1989.

FOSTER, Susan Leigh. Choreography and narrative: ballet's staging of story and desire. Bloomington: Indiana University Press, 1996.

GALLINI, Giovanni Andrea. A treatise on the art of dancing. Acesso através do site da Biblioteca do Congresso Nacional dos Estados Unidos através do site American Memory. Endereço eletrônico: http://memory.loc.gov/cgibin/ampage?collld=musdi\&fileName $=080 /$ musdi080.db\&recNum=1\&itemLink=r\%3Fa mmem\%2Fmusdi\%3A\%40field\%28DOCID\%2B\%40lit\%28M0808\%29\%29\%3A\%230 800136\&linkText=1. Londres: Impresso pelo autor, 1772.

HOMANS, Jennifer. Os anjos de Apolo: uma história do ballet. Edições 70. Lisboa. 2012. 


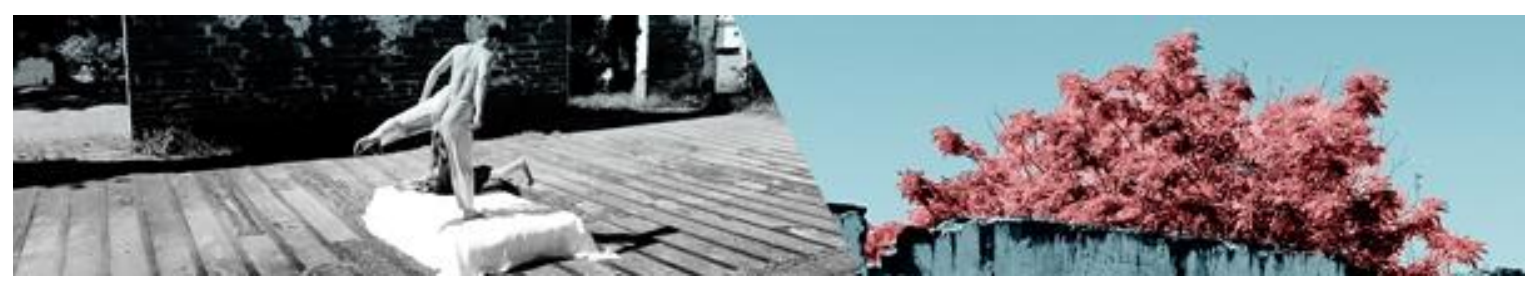

MARQUES, Isabel A. As propostas educacionais de Rudolf Laban: um olhar contemporâneo. In: Ensino de dança hoje - textos e contextos. São Paulo: Cortez, 1999.

MONTEIRO, Marianna. Natureza e Artifício no Balé de Ação. In: Noverre: Cartas sobre a dança/Marianna Monteiro: tradução e notas da autora - São Paulo: Editoria da Universidade de São Paulo: FAPESP: 1998.

NOVERRE, Jean-Georges. Cartas sobre a dança. In: MONTEIRO, Marianna. Noverre: Cartas sobre a dança / Marianna Monteiro: tradução e notas da autora São Paulo: Editoria da Universidade de São Paulo: FAPESP: 1998.

. Lettres sur les arts imitateurs en general et sur la danse en particulier. Chez Immerzelle et Compagnie. Paris. 1807. Fac-símile disponível no site da Biblioteca Nacional da França. Endereço eletrônico: http://gallica.bnf.fr/ark:/12148/bpt6k108202r/f4.image. Acesso em 17.03.2015, às $18 \mathrm{~h} 15 \mathrm{~min}$.

Nye, Edward. Mime, Music and Drama on the Eighteenth-Century Stage. Cambridge: Cambridge University Press, 2012.

WINSLOW, Jacob B. Exposition anatomique de la structure du corps humain. Tome second. Paris: P.F. Didot Libraire, 1776. Fac-Símile disponibilizado pela Universidade de Madrid. Endereço eletrônico: https://babel.hathitrust.org/cgi/pt?id=ucm.5329037078;view=1up;seq=7 . Acesso em 10.06.2017.

RAMEAU, Pierre, Le Maître a Danseur. J. Villette: Paris, 1725. Fac-símile disponível no site da Open Libraries, mantido pela York University, de Toronto/Canadá. Endereço eletrônico https://archive.org/details/lematredanserg00rameuoft. Acesso em 04.10.2015, às 09h44min.

LOURENÇO, Robson; VITIELLO, Júlia Ziviani. Contraponto em reflexão sobre a prática do balé: escavando camadas ósseas para a observação do mestre de dança através das cartas de JeanGeorges Noverre. Revista da FUNDARTE, Montenegro, p.484-504, ano 19, ํo 37, Janeiro/Março. Disponível em: http://.seer.fundarte.rs.gov.br/index.php/RevistadaFundarte/index> 30 de março de 2019. 